\title{
Genetic transformation of Knufia petricola A95 - a model organism for biofilm-material interactions
}

\author{
Steffi Noack-Schönmann ${ }^{1}$, Tanja Bus ${ }^{2}$, Ronald Banasiak ${ }^{1}$, Nicole Knabe ${ }^{1}$, William J Broughton ${ }^{1}$, H Den Dulk-Ras ${ }^{3}$, \\ Paul JJ Hooykaas ${ }^{3}$ and Anna A Gorbushina ${ }^{1,4^{*}}$
}

\begin{abstract}
We established a protoplast-based system to transfer DNA to Knufia petricola strain A95, a melanised rock-inhabiting microcolonial fungus that is also a component of a model sub-aerial biofilm (SAB) system. To test whether the desiccation resistant, highly melanised cell walls would hinder protoplast formation, we treated a melanin-minus mutant of A95 as well as the type-strain with a variety of cell-degrading enzymes. Of the different enzymes tested, lysing enzymes from Trichoderma harzianum were most effective in producing protoplasts. This mixture was equally effective on the melanin-minus mutant and the type-strain. Protoplasts produced using lysing enzymes were mixed with polyethyleneglycol (PEG) and plasmid pCB1004 which contains the hygromycin B (HmB) phosphotransferase (hph) gene under the control of the Aspergillus nidulans trpC. Integration and expression of hph into the A95 genome conferred hygromycin resistance upon the transformants. Two weeks after plating out on selective agar containing $\mathrm{HmB}$, the protoplasts developed cell-walls and formed colonies. Transformation frequencies were in the range 36 to 87 transformants per $10 \mu \mathrm{g}$ of vector DNA and $10^{6}$ protoplasts. Stability of transformation was confirmed by sub-culturing the putative transformants on selective agar containing $\mathrm{HmB}$ as well as by PCR-detection of the $h p h$ gene in the colonies. The hph gene was stably integrated as shown by five subsequent passages with and without selection pressure.
\end{abstract}

Keywords: DNA transfer; Fungal cell-walls; Protoplasts; Hygromycin resistance; Black yeast; Sub-aerial biofilms; Stress-protective morphology; Ancestor of opportunistic pathogens \& lichens

\section{Introduction}

Melanised microcolonial fungi (MCF) are a taxonomically diverse group of Ascomycetes that colonise sub-aerial rock surfaces and other varied materials in all regions of the world, from the Antarctic to hot deserts (Staley et al. 1982; Gorbushina et al. 1993; Urzi et al. 1995; Wollenzien et al. 1995; Sterflinger and Prillinger 2001; Ruibal 2004; Selbmann et al. 2005; Gorbushina 2007; Ruibal et al. 2008). MCF are characterised by simple stress-protective morphologies including a peculiar compact colonial structure, protective cell walls and multiple secondary metabolic products that support stress tolerance -

\footnotetext{
* Correspondence: anna.gorbushina@bam.de

${ }^{1}$ Department 4 (Materials \& Environment), Federal Institute for Materials Research and Testing (Bundesanstalt für Material-forschung und -prüfung, BAM), Unter den Eichen 87, 12205 Berlin, Germany

${ }^{4}$ Department of Biology, Chemistry and Pharmacy \& Department of Earth Sciences, Freie Universität Berlin, Malteserstrasse 74-100, 12249 Berlin, Germany

Full list of author information is available at the end of the article
}

carotenoids, melanins, mycosporines and compatible solutes (e.g. Gorbushina et al. 2008). For all these reasons MCF are unequalled amongst eukaryotes in their ability to withstand extreme heat, desiccation and UV radiation. MCF interact with accompanying phototrophic algae, cyanobacteria and heterotrophic bacteria to form a stable sub-aerial (SABs) microbial community (Gorbushina et al. 2005; Gorbushina 2007). At the extreme, MCF survival can depend on the small amounts of nutrients available in atmospheric aerosols, gases and air-borne particles - as well as on other SAB inhabitants (Gorbushina 2007). As a consequence of MCF stress tolerance, SABs are pioneer settlers on diverse surfaces exposed to air including artificial materials. Eventually SABs cause discoloration and deterioration of facades and roofs of buildings and are thus an important aspect of material science.

Knufia petricola A95 is a well suited model fungus to study organism-organism and organism-material interactions in SABs (Gorbushina and Broughton, 2009; 
Nai et al. 2013). As the rock-inhabiting K. petricola A95 belongs to an ancestral lineage of the Chaetothyriales (Ascomycetes) and is a predecessor of opportunistic pathogens and lichens (Gueidan et al. 2008), it is also of potential importance for understanding the evolution of Ascomycete life styles. Nevertheless, to be a tractable model organism, a reliable and efficient transformation system is essential (Perez-Nadales et al. 2014).

SABs are principal determinants of weathering of rocks (Gorbushina and Krumbein, 2000) and other materials exposed to air (e.g. Noack-Schönmann et al. 2014). SABs are important in the material sciences not only because they are omni-present on all exposed materials, but also because they degrade the surfaces to which they adhere. Weathering results and transparent surfaces become opaque restricting the passage of radiation (Hallbauer and Jahns, 1977; Jones and Wilson, 1985; Chen et al. 2000; Avakian et al. 1981; Jongmans et al. 1997; Gadd et al. 1999; Burford et al. 2003; Gorbushina et al. 1993; NoackSchönmann et al. 2014; Shirakawa, Zilles, Mocelin, Gaylarde, Gorbushina, Heidrich, Giudice, Del Negro, John. Microbial colonisation affects the efficiency of photovoltaic panels in a tropical environment, submitted to Science of the Total Environment). Diagnostic and prognostic tools for biofilm development on different materials and under various environmental conditions require easily accessible and genetically modifiable SABs. The establishment of a DNA-transfer- and integration-system into $K$. petricola A95 will set the stage for a variety of investigations into the role of MCFs in SAB formation and biofilminduced material deterioration.

An efficient transformation system is particularly important in dual-component systems like sub-aerial biofilms (SAB) where rock-inhabiting fungi form close inter- and intra-cellular contacts with phototrophic cells (Gorbushina et al. 2005). Gorbushina and Broughton (2009) proposed a model biofilm comprising the cyanobacterium Nostoc punctiforme and the MCF Knufia petricola (A95) as a new test system for the simulation of environment-biofilm interactions and their impact on materials. As an experimental model it is however essential that both partners be accessible to genetic manipulation. A transformation system exists for N. punctiforme (e.g. Risser and Meeks, 2013) and here we report a method for stably transforming $K$. petricola.

\section{Materials and methods}

\section{Strains and media}

K. petricola A95 (= CBS 123872) was isolated from the surface of a marble rock near the Philopappos monument on Musaios Hill, Athens (Greece) (Gorbushina et al. 2008). It is maintained in the culture collection of the Centraalbureau for Schimmelcultures (CBS 123872) in Utrecht and the Federal Institute for Materials Research and Testing in Berlin (A95). A spontaneous pink mutant of A95 deficient in melanin synthesis was isolated (A95p). The characteristic orange/pink colour of the mutant (Figure 1B) is caused by carotenoids (Gorbushina et al. 2008) that are normally masked by the melanised cell-wall. The type-strain (A95) and A95p were cultivated in liquid malt-extract medium (MEB) [2\% $(\mathrm{w} / \mathrm{v})$ malt extract, $0.1 \%(\mathrm{w} / \mathrm{v})$ peptone, $2 \%(\mathrm{w} / \mathrm{v})$ glucose] at $25^{\circ} \mathrm{C}$ and $100 \mathrm{rpm}$. The cultures were refreshed each week as described in Nai et al. (2013). A one week old culture was homogenised along with 10 steel balls (Ø $5 \mathrm{~mm}$ ) in a ball mill (Retsch ${ }^{\text {TM }}$, Retsch $\mathrm{GmbH}, 42781$ Haan, Germany) for $30 \mathrm{~s}^{-1}$ and $10 \mathrm{~min}$ then diluted 1:100 with fresh malt extract medium.

\section{Formation of protoplasts}

$300 \mathrm{ml}$ Erlenmeyer flasks containing $100 \mathrm{ml}$ of MEB were inoculated with $1 \mathrm{ml}$ of one-week-old freshly dispersed A95 and A95p cultures grown in MEB (experiments were duplicated for both strains). The cultures were grown for three days at $25^{\circ} \mathrm{C}$ and $100 \mathrm{rpm}$, spun down at $3,000 \times \mathrm{g}$ for 10 min and the resulting biomass washed three times with protoplast buffer $\left(0.01 \mathrm{M}\right.$ Tris $-\mathrm{HCl}, 0.01 \mathrm{M} \mathrm{MgSO}_{4}, 1 \mathrm{M}$ $\mathrm{KCl}, \mathrm{pH} 7.0$ (Walz and Kück, 1995)). Different enzyme combinations were added to $2 \times 10^{7}$ cfu A95 in $20 \mathrm{ml}$ protoplast buffer. The enzymes used were: (i) a mixture of Vinoflow (Novozymes, Bagsvaerd, Denmark), Yatalase (Takara, Shiga Japan) and B-glucanase (Aspergillus niger) (Sigma-Aldrich, Steinheim, Germany)(each $10 \mathrm{mg} \cdot \mathrm{ml}^{-1}$ ) (ii) Lysing enzymes from Trichoderma harzianum (SigmaAldrich)(10mg.ml ${ }^{-1}$ ) and (iii) a mixture of Driselase (Sigma-Aldrich), Lyticase (Sigma-Aldrich) and ß-glucanase (A.niger) (Sigma-Aldrich) also at $10 \mathrm{mg}^{-\mathrm{ml}^{-1}}$. The A95enzyme mixes were incubated at $27^{\circ} \mathrm{C}$ and $100 \mathrm{rpm}$ for 24 $\mathrm{h}$. The efficiency of protoplast formation (ratio of protoplasts to the number of A95 cells still surrounded by cell walls) was determined in $10 \mu \mathrm{l}$ aliquots by counting in a Neubauer chamber. For transformation, the protoplasts were centrifuged for $5 \mathrm{~min}$ at 3,000 $\times \mathrm{g}$, washed several times with transformation buffer [1M sorbitol, $80 \mathrm{mM}$ $\mathrm{CaCl}_{2}$, pH 7.0 (Walz and Kück, 1993)] and re-suspended in the same buffer at a final concentration of $5 \times 10^{7} \cdot \mathrm{ml}^{-1}$.

\section{Recombinant plasmids}

The hygromycin selection vector for PEG mediated transformation pCB1004 (Carroll et al. 1994) was used. pCB1004 contains the hygromycin B phosphotransferase gene ( $h p h)$ under control of the A. nidulans trpC promoter (Mullaney et al. 1985) but without the $\operatorname{trpC}$ terminator. pCB1004 also contains a chloramphenicol resistance cassette, a functional lacZ gene and a multiple cloning site (Figure 2). 

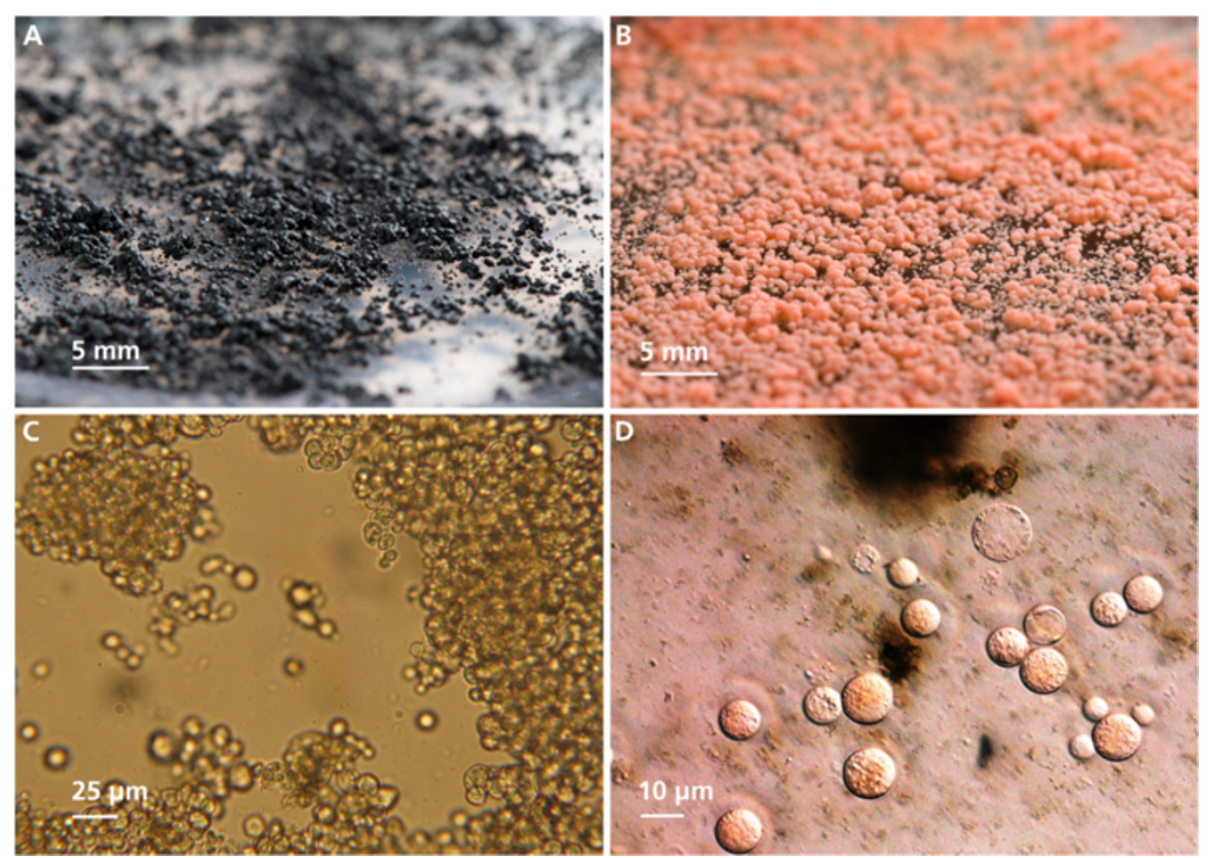

Figure 1 Knufia petricola A95 morphology. A- Being a typical MCF, K. petricola A95 retains protective pigmentation and restricted colony growth even under favourable growth conditions on a Petri dish; B - As a result of a spontaneous mutation, the A95 pink mutant (A95p) is deficient in melanin synthesis. The orange/red colour is caused by carotenoids that are normally masked by melanins. C- Micrograph of A95 cells with melanin. The ball-shaped, compact A95 cells are surrounded by a thick cell-wall and are embedded in extracellular polymeric substances that are arranged in compact clusters of cells. D- A95 protoplasts prepared from similar cells to those shown in Figure 1C. A95 protoplasts were most effectively isolated by digestion of the cell-wall using lysing enzymes from Trichoderma harzianum and prevented from bursting in a $1 \mathrm{M} \mathrm{KCl} \mathrm{buffer.}$

\section{PEG mediated transformation}

$50 \mu \mathrm{l}\left(\approx 10^{6}\right)$ protoplasts, re-suspended in transformation buffer, were incubated with $10-20 \mu \mathrm{g}$ of plasmid DNA for $20 \mathrm{~min}$ at $4^{\circ} \mathrm{C} .100 \mu \mathrm{l}$ of $24 \%$ (w/v) PEG 6000 was added, gently mixed and incubated for 30 min at room temperature. Five $\mathrm{mL}$ MEBS [malt extract broth with $10.8 \%(\mathrm{w} / \mathrm{v})$ sucrose] containing 150 $\mu \mathrm{l}$ transformation mix was distributed over five MEAS-plates [malt-extract agar with $10.8 \%(\mathrm{w} / \mathrm{v})$ sucrose]. After incubation at $25^{\circ} \mathrm{C}$ for $24 \mathrm{~h}$, the plates were overlain with $5 \mathrm{ml}$ of selective agar $[0.8 \mathrm{M}$ $\mathrm{NaCl}, 0.4 \% \mathrm{w} / \mathrm{v}$ ) agar, final concentration of $0.25 \mathrm{mg}$ of HygB.ml ${ }^{-1}, \mathrm{pH}$ 7.0] and incubated for 3 to 4 weeks at $25^{\circ} \mathrm{C}$.

\section{Isolation of fungal DNA}

A95 cells were frozen in liquid nitrogen and ground with a mortar and pestle. $100 \mathrm{mg}$ of the ground cells was mixed with $500 \mu \mathrm{l}$ Genomic Lysis Buffer (OmniPrep ${ }^{\mathrm{TM}}$ for Fungus Kit, G-Biosciences, St. Louis, MO 631321429, U.S.A.) and total DNA isolated using the same kit according to the manufacturer's instructions. Five randomly selected A95 transformants were used for total DNA isolation and amplification of the $h p h$ gene.

\section{Amplification of the hygromycin B phosphotransferase gene (hph)}

On the assumption that the hygromycin B phosphotransferase gene $(h p h)$ was integrated randomly into the genome of A95, total genomic DNA of the transformants was amplified with the primer pair hphRforw (5'-ATGCCTGAACTCACCGCGAC-3') and hphRrev (5'-CTATTCCTTTGCCCTCGGACGAG-3'). PCR reactions were carried out with ReproFast-DNA Polymerase (Genaxxon Bioscience, 89007 Ulm, Germany) under the following conditions: initial denaturation at $96^{\circ} \mathrm{C}$ for $30 \mathrm{~s}$, followed by 30 cycles of denaturation at $96^{\circ} \mathrm{C}$ for $30 \mathrm{~s}$, annealing at $54^{\circ} \mathrm{C}$ for $30 \mathrm{~s}$, extension at $72^{\circ} \mathrm{C}$ for $2 \mathrm{~min}$, terminated by 10 min extension at $72^{\circ} \mathrm{C}$. The PCR products were sequenced.

\section{Mitotic stability of the A95 transformants}

Five randomly selected colonies were transferred to $5 \mathrm{ml}$ MEA, mixed with 10 steel balls $(\varnothing 5 \mathrm{~mm})$, vigorously shaken in a Retsch ${ }^{\mathrm{TM}}$ mill for $10 \mathrm{~min}$ at $30 \mathrm{~Hz}$ and subcultured on MEA with and without hygromycin B. The putative transformants were subcultured five times on selective or non-selective agar. After five rounds of 


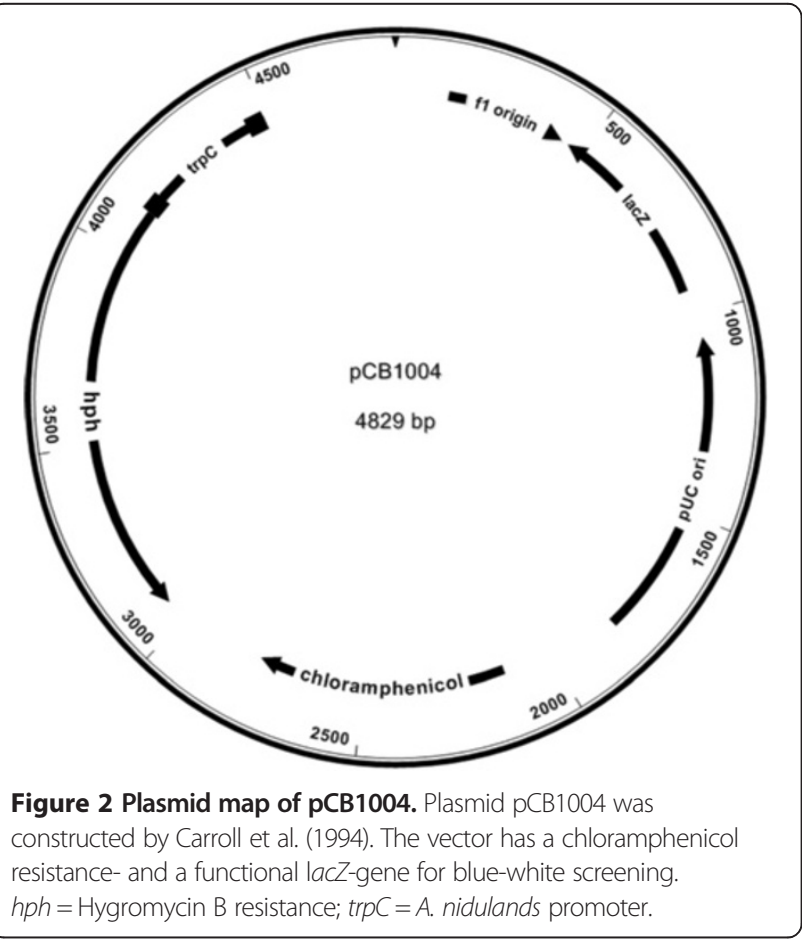

non-selective subculture, the transformants were transferred to MEA plates containing $50 \mu \mathrm{g} \cdot \mathrm{ml}^{-1}$ hygromycin B. This experiment was repeated twice.

\section{Results}

Different ways of transforming A95 were tested (S. Noack-Schönmann et al. unpublished results). These included the commonly used binary Ti-vector system of $A$. tumefaciens (De Groot et al. 1998, Michielse 2005a; 2005b; 2008) which failed to yield transformants in our hands. As A95 is strongly melanised, problems in penetrating the melanised and as a consequence thick cell wall were expected. Chemical weakening of the cell wall with DMSO before addition of A. tumefaciens was also unsuccessful. Bombardment of A95 with microprojectiles (Lorito et al. 1993; Te'o et al. 2002) coated with pTAS5 and pCB1004 plasmid DNA did not yield transformants. Finally different enzyme preparations containing various chitinases and $\beta$-glucanases were tested to establish an efficient protocol for the isolation of protoplasts. Armed with an effective protocol for the production of protoplasts, we used the vector pCB1004 carrying the hygromycin resistance gene and polyethylene glycol to transfer hygromycin resistance to A95.

\section{Protoplast isolation}

All enzymes and enzyme mixtures tested yielded protoplasts (Figure 1D and Table 1). At best, the protoplast yields were ten percent of the intact cells subjected to
Table 1 Efficiency of protoplast isolation from A95 cells using different cell-wall lysing enzymes

\begin{tabular}{lll}
\hline $\begin{array}{l}\text { Enzymes used for } \\
\text { protoplast isolation }\end{array}$ & $\begin{array}{l}\text { Starting number of } \\
\text { A95 cells (cfu.mL }\end{array}$ & $\begin{array}{l}\text { Number of } \\
\text { protoplasts } \\
\text { isolated.mL }\end{array}$ \\
\hline $\begin{array}{l}\text { Lysing enzymes from } \\
\text { Trichoderma harzianum }\end{array}$ & $2 \times 10^{7}$ & $2.0 \times 10^{6}$ \\
$\beta-$-Glucanase, Vinoflow, Yatalase & $2 \times 10^{7}$ & $1.9 \times 10^{6}$ \\
Driselase, $\beta$-Glucanase, Lyticase & $2 \times 10^{7}$ & $1.1 \times 10^{6}$ \\
\hline
\end{tabular}

the enzyme treatment (Table 1). Clearly, the mixture Driselase, $ß$-Glucanase and Lyticase was only about half as efficient as the other two treatments. On the other hand, there were no significant differences in protoplast yields obtained with the lysing enzymes of $T$. harzianum and the mixture $B$-Glucanase, Vinoflow and Yatalase. As preparation of the $T$. harzianum mix is simpler and more cost effective, we used this procedure in all further experiments. Black A95 cells (A95) and cells of a pink melanin-deficient A95 mutant (A95p) (Figure 1) were subjected to treatment with lysing enzymes of $T$. harzianum as described above. Although higher than in preliminary experiments, protoplast yields were the same for both cell types (Table 2).

\section{Transformation of A95 protoplasts}

Colonies were visible on hygromycin B containing MEAS agar two to three weeks after transformation of A95 protoplasts with pCB1004 (Figure 3A). Five randomly selected, transformed colonies were able to grow when plated out again on hygromycinB-containing agar. Total DNA from some of these re-picked colonies was amplified by PCR using the primer pair hphRforw/ hphRrev resulting in an amplicon of $\approx 1,000 \mathrm{bp}$, which is consistent with the size $(1,020 \mathrm{bp})$ of the $h p h$-gene (Figure 3B). The sequences of all PCR products matched completely those of $h p h$. About 55 transformants were obtained from $10^{6}$ protoplasts in a total volume of 150 $\mu \mathrm{l}$ containing 10 to $20 \mu \mathrm{g}$ plasmid DNA.

\section{Mitotic stability}

All randomly selected A95 transformants maintained hygromycin resistance after multiple passages on MEA

Table 2 Efficiency of protoplast isolation from A95 and a pink A95 derivative

\begin{tabular}{lll}
\hline & $\begin{array}{l}\text { Starting number of } \\
\text { cells (cfu.mL }\end{array}$ & $\begin{array}{l}\text { Number of protoplasts } \\
\text { isolated.mL }\end{array}$ \\
\hline A95 & $5 \times 10^{6}$ & $1.1 \times 10^{6}$ \\
Pink derivative of A95 & $5 \times 10^{6}$ & $1.1 \times 10^{6}$ \\
\hline
\end{tabular}



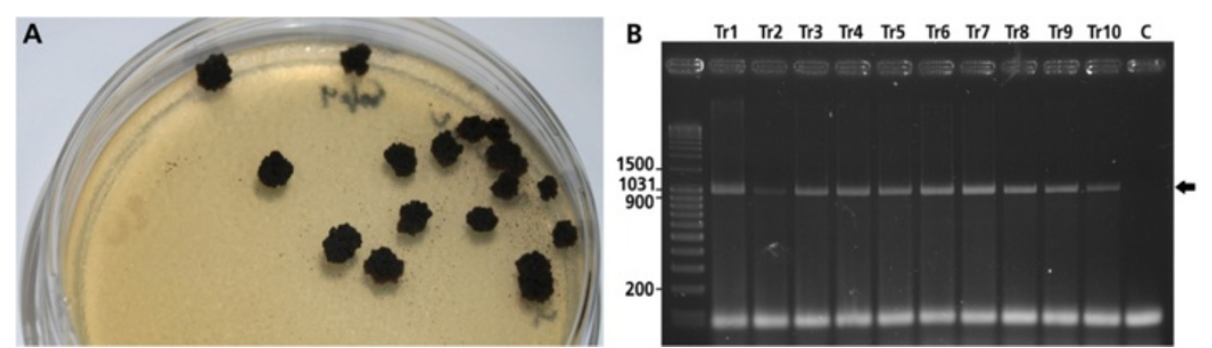

Figure 3 A95 transformants. A- three weeks after PEG mediated transformation of A95 protoplasts with pCB1004, single A95 colonies were observed on malt-extract agar plates containing hygromycin. B- PCR products of the hph-gene (1,019 bp) seen on agarose gels. Polymerase chain reaction detection of the $h p h$-gene from DNA of five independent putative transformants confirmed integration of hph into the genome of A95 transformants. Arrow indicates location of hph DNA bands.

with or without hygromycin. After subculturing five times without selection pressure (MEA without hygromycin), five formerly hygromycin-resistant colonies were still able to grow when plated out again on hygromycin containing MEA.

\section{Discussion}

An assembly of methods that are used for transformation of filamentous fungi were tested in preliminary experiments, but only PEG-mediated transformation of protoplasts showed promise. We performed PEGmediated transformation of A95 protoplasts with pTAS5 (de Groot et al. 1998) and pCB1004 (Carroll et al. 1994), but only obtained transformants using pCB1004. Perhaps the TAS5 vector $(11.8 \mathrm{~kb})$ was too large to escape restriction on entering the A95 protoplasts or the gpdA promoter was less efficient in $\mathrm{A} 95$ than the $\operatorname{trpC}$ promoter.

Incubation of protoplasts with pCB1004 and PEG allowed integration of the hygromycin $\mathrm{B}$ resistance cassette (under control of the $\operatorname{trp} \mathrm{C}$ promoter) into the genome of A95. All hygromycin B resistant colonies selected maintained resistance to hygromycin during five rounds of subculturing on selective or non-selective agar. Most probably transformation efficiencies can be improved by for example optimising the ratio between applied plasmid-DNA and the number of cells. Various preparations containing a complex mixture of hydrolytic enzymes were tested (Table 1) for preparation of transformable protoplasts. Lysing enzymes of Trichoderma harzianum were most effective in isolating protoplasts from A95 cells (Table 1). Further improvement of the protoplast isolation protocol by testing different enzyme concentrations and various incubation temperatures could also be tried. Interestingly, melanin from the pigmented walls did not interfere with protoplast isolation since the efficiency of protoplast formation was the same using type A95 cells and a melanin-deficient mutant (Table 2).
Stable integration of the hygromycin-resistance gene into the A95 genome showed that illegimate recombination is possible in Knufia petricola A95. Whether this means that homologous recombination also occurs at a frequency that would permit genereplacement remains to be determined. Nevertheless, the methods described here permit exploration of A95 using reverse genetic tools. Armed with these tools, it should be possible to discover the mechanisms which A95 and other rock-inhabiting melanised fungi use to colonise inhospitable sub-aerial surfaces so successfully.

\section{Competing interests}

The authors declare that they have no competing interests.

\section{Authors' contributions}

SNS performed many types of experiments to produce protoplasts and transform them, actively participated in the design of the study and drafted a preliminary manuscript containing Figures 1 and 3. TB prepared many batches of protoplasts. NK conducted the transformation experiments and prepared Figures 2 and 3. RB assisted in all experiments conducted at the BAM and attempted transformation using the "GeneGun". HDDR, PJJH and WJB initiated protoplast isolation and Agrobacterium-mediated transformation experiments in the Leiden laboratories. They also participated in the design of later experiments. WJB shaped the presentation of the material written. AAG conceived the study, participated in its design and coordination, helped to interpret the data and write the manuscript. All authors read and approved the final manuscript.

\section{Acknowledgements}

We thank Dr. Zheng Wang for the plasmid pCB1004, Prof. Thomas Schmülling and Prof. Wolfgang Schuster (Freie Universität Berlin) for use of their Gene Gun ${ }^{\mathrm{TM}}$ equipment in transformation experiments and Thorsten Doil (BAM) for collating the figures. This work was supported financially by internal funds of the BAM.

\section{Author details}

${ }^{1}$ Department 4 (Materials \& Environment), Federal Institute for Materials Research and Testing (Bundesanstalt für Material-forschung und -prüfung, BAM), Unter den Eichen 87, 12205 Berlin, Germany. ${ }^{2}$ Department of Biotechnology, University of Applied Sciences Jena, Carl-Zeiß-Promenade 2, 07745 Jena, Germany. ${ }^{3}$ Institute of Biology Leiden, Universiteit Leiden, Sylviusweg 72, 2333 BE Leiden, The Netherlands. "Department of Biology, Chemistry and Pharmacy \& Department of Earth Sciences, Freie Universität Berlin, Malteserstrasse 74-100, 12249 Berlin, Germany. 
Received: 13 August 2014 Accepted: 15 October 2014

Published online: 04 November 2014

\section{References}

Avakian ZA, Karavaiko Gl, Mel'nikova EO, Krutsko VS, Ostroushko II (1981) Role of microscopic fungi in the process of weathering of pegmatite deposit rocks and minerals. Mikrobiologiya 50:156-162

Burford EP, Fomina M, Gadd GM (2003) Fungal involvement in bioweathering and biotransformation of rocks and minerals. Miner Mag 67:1127-1155

Carroll AM, Sweigard JA, Valent B (1994) Improved vectors for selecting resistance to hygromycin. Fungal Genet Newsl 41:22

Chen J, Blume HP, Beyer $L$ (2000) Weathering of rocks induced by lichen colonization-a review. Catena 39:121-146

De Groot MJA, Bundock P, Hooykaas PJJ, Beijersbergen GM (1998) Agrobacterium tumefaciens-mediated transformation of filamentous fungi. Nat Biotechnol 16:839-842

Gadd GM (1999) Fungal production of citric and oxalic acid: importance in metal speciation, physiology and biogeochemical processes. Adv Microb Physiol 41:47-92

Gorbushina AA (2007) Life on the rocks. Environ Microbiol 9:1613-1631

Gorbushina AA, Broughton WJ (2009) Microbiology of the atmosphere-rock interface: How biological interactions and physical stresses modulate a sophisticated microbial ecosystem. Ann Rev Microbiol 63:431-450

Gorbushina AA, Krumbein WE (2000) Subaerial microbial mats and their effects on soil and rock. P. 161-170. In: Riding RE, Awramik SM (eds) Microbial Sediments. Springer, Berlin, p 331

Gorbushina AA, Krumbein WE, Panina L, Soukharjevski S, Wollenzien U (1993) On the role of black fungi in colour change and biodetioration of antique marbles. Geomicrobiol J 11:205-221

Gorbushina AA, Beck A, Schulte A (2005) Microcolonial rock inhabiting fungi and lichen photobionts: evidence for mutualistic interactions. Mycol Res 109:1288-1296

Gorbushina AA, Kotlova ER, Sherstneva OA (2008) Cellular responses of microcolonial rock fungi to long-term desiccation and subsequent rehydration. Stud Mycol 61:91-97

Gueidan C, Villasenor CR, de Hoog GS, Gorbushina AA, Untereiner WA, Lutzoni F (2008) A rock-inhabiting ancestor for mutualistic and pathogen-rich fungal lineages. Stud Mycol 61:111-119

Hallbauer DK, Jahns HM (1977) Attack of lichens on quartzitic rock surfaces. Lichenologist 9:119-122

Jones D, Wilson MJ (1985) Chemical activity of lichens on mineral surfaces - a review. Int Biodeterior Biodegradation 21:99-104

Jongmans AG, van Breemen N, Lundstrom U, van Hees PAW, Finlay RD, Srinivasan M, Unestam T, Giesler R, Melkerud PA, Olsson M (1997) Rockeating fungi. Nature 389:682-683

Lorito M, Hayes CK, Di Pietro A, Harman GE (1993) Biolistic transformation of Trichoderma harzianum and Gliocladium virens using plasmid and genomic DNA. Curr Genet 24:349-356

Michielse CB, Arentshorst M, Ram AF, van den Hondel CA (2005a) Agrobacteriummediated transformation leads to improved gene replacement efficiency in Aspergillus awamori. Fungal Genet Biol 42:9-19

Michielse CB, Hooykaas PJ, van den Hondel CA, Ram AF (2005b) Agrobacteriummediated transformation as a tool for functional genomics in fungi. Curr Genet 48:1-17

Michielse CB, Hooykaas PJJ, van den Hondel CAMJJ, Ram AFJ (2008) Agrobacterium-mediated transformation of the filamentous fungus Aspergillus awamori. Nat Protoc 3:1671-1678

Mullaney EJ, Hamer JE, Yelton MM, Timberlake WE (1985) Primary structure of the trpC gene from Aspergillus nidulans. Mol Gen Genet 199:37-45

Nai C, Wong HY, Pannenbecker A, Broughton WJ, Benoit I, de Vries RP, Gueidan C, Gorbushina AA (2013) Nutritional physiology of a rock-inhabiting, model micro-colonial fungus from an ancestral lineage of the Chaetothyriales (Ascomycetes). Fungal Genet Biol 56:54-66

Noack-Schönmann S, Spagin O, Gründer K-P, Breithaupt M, Günter A, Muschik B, Gorbushina AA (2014) Sub-aerial biofilms as blockers of solar radiation: spectral properties as tools to characterise material-relevant microbial growth. Intern Biodeterior Biodegradation 86:286-293

Perez-Nadales E, Almeida Nogueira MF, Baldin C, Castanheira S, El Ghalid M, Grund E, Lengeler K, Marchegiani E, Vinod Mehrotra P, Moretti M, Naik V, Oses-Ruiz M, Oskarsson T, Schäfer K, Wasserstrom L, Brakhage AA, Gow NAR, Kahmann R, Lebrun M-H, Perez-Martin J, Di Pietro A, Talbot NJ, Toquin V,
Walther A, Wendland J (2014) Fungal model systems and the elucidation of pathogenicity determinants. Fungal Genet Biol 70:42-67

Risser DD, Meeks JC (2013) Comparative transcriptomics with a motility-deficient mutant leads to identification of a novel polysaccharide secretion system in Nostoc punctiforme. Mol Microbiol 87:884-893

Ruibal CV (2004) Isolation and Characterization of Melanized, Slow-growing Fungi from Semiarid Rock Surfaces of Central Spain and Mallorca. Ph.D. Dissertation. Universidad Autónoma de Madrid; Merck, Sharp \& Dohme de Espana, Madrid

Ruibal CV, Platas G, Bills GF (2008) High diversity and morphological convergence among melanised fungi from rock formations in the Central Mountain System of Spain. Persoonia 21:93-110

Selbmann L, de Hoog GS, Mazzaglia A, Friedmann E, Onofri S (2005) Fungi at the edge of life: cryptoendolithic black fungi from Antarctic desert. Stud Mycol 51:1-32

Staley JT, Palmer F, Adams JB (1982) Microcolonial fungi: common inhabitants on desert rocks? Science 215:1093-1095

Sterflinger K, Prillinger H (2001) Molecular taxonomy and biodiversity of rock fungal communities in an urban environment (Vienna, Austria). Antonie Van Leeuwenhoek 80:275-286

Te'o VSJ, Bergquist PL, Nevalainen KMH (2002) Biolostic transformtaion of Trichoderma reesei using the Bio-Rad seven barrels Hepta Adaptor system. J Microbiol Meth 51:393-399

Urzi C, Wollenzien U, Criseo G, Krumbein WE (1995) Biodiversity of the rock inhabiting microbiota with special reference to black fungi and black yeasts. In: Allsopp D, Colwell RR, Hawksworth DL (eds) Microbial Diversity and Ecosystem Function. CAB International, Wallingford, pp 289-302

Walz M, Kück U (1993) Targeted integration into the Acremonium chrysogenum genome: disruption of the $p c b C$ gene. Curr Genet 24:421-427

Walz M, Kück U (1995) Transformation of Sordaria macrospora to hygromycin B resistance: characterization of transformants by electrophoretic karyotyping and tetrad analysis. Curr Genet 29:88-95

Wollenzien U, de Hoog GS, Krumbein WE, Urzi C (1995) On the isolation of microcolonial fungi occurring on and in marble and other calcareous rocks. Sci Total Environ 167:287-294

doi:10.1186/s13568-014-0080-5

Cite this article as: Noack-Schönmann et al:: Genetic transformation of Knufia petricola A95 - a model organism for biofilm-material interactions. AMB Express 2014 4:80.

\section{Submit your manuscript to a SpringerOpen ${ }^{\odot}$ journal and benefit from:}

- Convenient online submission

$\checkmark$ Rigorous peer review

- Immediate publication on acceptance

- Open access: articles freely available online

- High visibility within the field

- Retaining the copyright to your article

Submit your next manuscript at $>$ springeropen.com 